\title{
Peningkatan Kemampuan Menulis Karya Ilmiah Menggunakan Media Video Faststone di Masa Pandemi COVID-19
}

\author{
Agus Darmuki*, Ahmad Hariyadi, Nur Alfin Hidayati \\ IKIP PGRI Bojonegoro \\ *agus_darmuki@yahoo.co.id
}

\begin{abstract}
This study aims to obtain a description of increasing student activeness and learning outcomes in learning to write scientific papers using faststone media during the Covid-19 pandemic in PGSD Study Program FKIP Students of the Surakarta Open University Academic Year 2020.1. This type of research is Classroom Action Research with two cycles consisting of two meetings in one cycle. Each cycle consists of planning, implementing, observing, and reflecting. Data analysis techniques in this study used data triangulation techniques consisting of (1) data collection; (2) data reduction; (3) drawing conclusions on the data in the form of documents of student work results and a list of scores. The results of this study indicate that learning to write scientific papers in cycle I to cycle II there is an increase, in cycle I the number of students who got a complete score was 20 students or $71 \%$, the incomplete score in cycle I was 8 students or $29 \%$, while in cycle I the number of students who got a complete score was 20 students or $71 \%$. 2 there was an increase in the completeness score, namely to 23 students or $82 \%$. The conclusion of this research is that learning to write scientific papers using Faststone media can improve learning outcomes and activeness of the I A Students of PGSD UT Surakarta Study Program.

Keywords: Writing; Scientific work; Faststone media; Pandemic; Covid-19.
\end{abstract}

\section{ABSTRAK}

Penelitian ini bertujuan untuk memperoleh deskripsi tentang peningkatan keaktifan dan hasil belajar Mahasiswa dalam pembelajaran menulis karya ilmiah menggunakan media faststone di masa pandemic covid - 19 pada Mahasiswa Prodi PGSD FKIP Universitas Terbuka Surakarta Tahun Akademik 2020.1. Jenis penelitian ini adalah Penelitian Tindakan Kelas dengan dua siklus yang terdiri dari dua kali pertemuan dalam satu siklus. Setiap siklus terdiri dari perencanaan, pelaksanaan, observasi, dan refleksi. Teknik analisis data dalam penelitian ini menggunakan teknik triangulasi data yang terdiri dari (1) pengumpulan data; (2) reduksi data; (3) penarikan simpulan terhadap data berupa dokumen hasil pekerjaan Mahasiswa dan daftar nilai. Hasil penelitian ini menunjukkan bahwa pembelajaran menulis karya ilmiah pada siklus I ke siklus II terdapat peningkatan, pada siklus I jumlah Mahasiswa yang mendapat nilai tuntas adalah 20 Mahasiswa atau $71 \%$, nilai tidak tuntas pada siklus I adalah 8 Mahasiswa atau $29 \%$, sedangkan pada siklus 2 terjadi peningkatan nilai tuntas yaitu menjadi 23 Mahasiswa atau $82 \%$

. Kesimpulan penelitian ini pembelajaran menulis karya ilmiah menggunakan media Faststone dapat meningkatkan hasil belajar dan keaktifan Mahasiswa I A Prodi PGSD UT Surakarta.

Kata Kunci: Menulis; Karya ilmiah; Media Faststone; Pandemi; Covid-19.

Submitted Apr 20, 2021 | Revised May 02, 2021 | Accepted May 05, 2021

\section{Pendahuluan}

Menulis adalah aktivitas pengekpresian ide, gagasan, pikiran atau perasaan ke dalam lambanglambang kebahasaan dengan tujuan tertentu (Zahroh, 2017). Keterampilan menulis karya ilmiah merupakan keterampilan penting yang harus dikuasai Mahasiswa (Sarmadan, 2017) dalam Prodi PGSD UT Surakarta. Dalam pembelajaran di kelas biasanya dosenakan mengajarkan Mahasiswa menulis karya ilmiah dengan menyampaikan materi tentang struktur karya ilmiah melalui daring dengan membagi PPT melalui aplikasi microsoft teams. Biasanya sebelum masuk ke materi Mahasiswa diberikan apersepsi dan motivasi sudah belajar / membaca materi teknik menulis karya ilmiah dari modul yang sudah diterima. Keterampilan menulis di Prodi PGSD Universitas Surakarta diajarkan pada mata kuliah teknik penulisan karya ilmiah. Mata kuliah tersebut sebagai prasyarat untuk mengambil mata kuliah PKP berpraktif dengan luaran laporanan dan unggah karya ilmiah di jurnal UT. 
Keterampilan menulis merupakan ketrampilan yang sangat penting dan harus dikuasai oleh Mahasiswa Prodi PGSD karena menjadi prasyarat untuk bisa lulus harus menulis kary ilmiah dan dipublikasikan. Keterampilan menulis biasanya akan disandingkan dengan keterampilan membaca seperti dikte atau membaca teks bacaan dan membuat kalimat. Modul yang digunakan untuk panduan menulis Mahasiswa Prodi PGSD adalah modul penulisan karya ilmiah karya tim penulis UT sendiri. Modul ini dirancang supaya Mahasiswa belajar mandiri menulis karya ilmiah yang didampingi oleh tutor yang membimbing mahasiswa untuk menyelesaikan modul tersebut. Setiap Mahasiswa memiliki karakteristik yang berbeda (Darmuki, 2020) dalam menulis karya ilmiah tetap memperhatikan panduan dan format penulisan karya ilmiah. Tugas dosen/tutor mengajarkan menulis karya ilmiah yang benar supaya tidak ada kesalahan. Keterampilan menulis karya ilmiah ini merupakan bagian terpenting untuk pengajaran berikutnya. Tutor harus sabar membimbing dan melatih Mahasiswanya agar tercapai suatu tujuan pembelajaran dengan luaran karya ilmiah mahasiswa .Sebaliknya kegagalan pembelajaran menulis karya ilmiah akan berakibat pada kegagalan penguasaan modul dan pembelajaran mandiri mahasiswa . Mahasiswa diminta menulis karya ilmiah sesuai dengan template jurnal yang dituju atau sesuai dengan format penulisan karya ilmiah pada modul.

Dalam pembelajaran menulis karya ilmiah Mahasiswa diajarkan tentang membuat judul, menyusun abstrak, menulis latar belakang, kajian teori, metode, hasil dan pembahasan, dan cara menulis referensi atau daftar pustaka dari berbagai sumber seperti dari buku, jurnal dll. agar mahasiswa mudah memahami. Menulis karya ilmiah merupakan keterampilan yang mesti dilatih dan dibiasakan untuk bisa memperoleh hasil maksimal. Pelaksanaan menulis karya ilmiahdibagi menjadi dua menulis karya ilmiah hasil penelitian dan menulis karya ilmiah non hasil penelitian. Seringkali terjadi jika menulis karya ilmiah pada Mahasiswa memiilih menggunakan karya ilmiah hasil penelitian menjadi jenuh dan terlalu formal. Apalagi kalau menulisnya banyak dan harus berdasarkan hasil penelitian atau data-data lapangan. Menulis karya ilmiah harus bertahap diawali dari menulis karya ilmiah non hasil penelitian yang berupa gagasan untuk melatih mahasiswa berasumsi dari teori referensi yang dibacanya. Baru kemudian meningkatkan menulis karya ilmiah hasil penelitian dengan desain pembelajaran yang tidak kaku dan tidak membosankan. Maka tutor seharusnya menciptakan suasana yang menyenangkan bagi Mahasiswa saat pembelajaran (Darmuki dkk., 2019), bukan dengan suasana pembelajaran yang kaku, sehingga Mahasiswa mampu menguasai keterampilan menulis.

Pelaksanaan pembelajaran menulis karya ilmiah di Prodi PGSD UT Surakarta selama masa pandemi covid- 19 menggunakan media faststonedengan aplikasi microsoft teems. Kondisi pandemi covid19 pendidik dituntut kreatif menggunnakan media pembelajaran berbasis online (Anhusadar, 2020; Burke dkk., 2009; Baskoro, 2009). Selain itu pembelajaran harus terjadi interaksi yang berkualitas dan efektif (Darmuki \& Hidayati, 2019; Darmuki \& Hariyadi, 2019) serta memicu motivasi mahasiswa dalam kegiatan pembelajaran (Darrmuki dkk., 2017) sehingga terjadi proses transfer informasi pengetahuan ke mahasiswa (Darmuki dkk., 2018). Tutor membuat tutorial cara menulis karya ilmiah untuk mahasiswa PGSD. Berdasarkan observasi awal (hasil pengumpulan tugas) setiap pertemuan ke 3, 5 dan 7 ada beberapa mahasiswa yang tulisannya belum sesuai mulai dari bentuk format, ketepatan dalam meletakkan bagian dari jurnal sehingga hasil evaluasi belajarnya masih rendah. Keaktifan mahasiswa dalam pembelajaran juga belum terlihat. Mahasiswa belum paham cara menulis karya ilmiah. Oleh karena itu perlu perbaikan pembelajaran kearah lebih baik salah satunya menggunakan media video faststone. Kegiatan pembelajaran menulis karya ilmiah perlu dilakukan dengan metode ceramah dan variasi tanya jawab dan direkam dengan menggunakan video faststone agar pembelajaran menulis menjadi lebih efektif. Kelebihan dari media faststone ini adalah : 1) Sederhana dan mudah digunakan, 2) Dapat mengatasi batasan ruang dan waktu, keterbatasan pengamatan, memperjelas masalah bidang apa saja, serta mudah di dapat dan digunakan, 3) Sebagai salah satu teknik media pembelajaran yang efektif, karena mengkombinasikan merekam seluruh aktivitas yang tampil di layar PC dan menyimpannya menjadi file video melalui pengungkapan menulis karya ilmiah. 
Setelah adanya refleksi diri dan diskusi dengan rekan sejawat pada pembelajaran menuliskarya ilmiah maka ada beberapa faktor yang menyebabkan prestasi Mahasiswa kurang dalam pembelajaran tersebut. Hasil analisa masalah yang telah dilakukan adalah sebagai berikut : a) Tutor belum memberikan perhatian penuh terhadap fokus Mahasiswa menulis karya ilmiah, b) Tutor kurang menarik dan bervariasi dalam menyampaikan pembelajaran menulis karya ilmiah, c) Tutor masih kurang dalam memberikan contoh kepada Mahasiswa.

Dari latar belakang serta identifikasi masalah yang dituliskan diatas, maka alternatif pemecahan masalah yang sesuai yaitu menerapkan pembelajaran menulis karya ilmiah dengan Media Video Faststone. Media tersebut dianggap sesuai karena dengan media tersebut diharapkan Mahasiswa bisa ikut berperan aktif dalam pembelajaran sehingga pembelajaran menulis karya ilmiah menjadi menarik dan konsentrasi Mahasiswa bisa fokus terhadap pembelajaran menulis karya ilmiah yang sedang berlangsung.

FastStone adalah sebuah aplikasi yang mudah digunakan dan sangat simple untuk membuat tutorial atau merekam pada dekstop di layar komputer.(tekamjad, 2018). Biasanya aplikasi FastStone digunakan untuk membuat tutorial-tutorial yang menampilkan langsung layar laptop, misal: tutorial desain coreldraw, tutorial desain photoshop. Dengan menampilkan video tutorial tersebut akan memudahkan mahasiswa dalam belajar (DeWitt dkk., 2013). Di Masa Pandemi Covid-19, media Faststone digunakan sebagai media pembelajaran bagi Mahasiswa selama pembelajaran daring. Penggunaan media Faststonediharapkan sangat membantu tutor dalam menerangkan menulis karya ilmiah. Tutor membuat power point tentang pembelajaran yang akan diterangkan kepada Mahasiswa . Tutor memulai rekaman dengan menggunakan kata-kata dan bahasa yang mudah dipahami oleh Mahasiswa . Jika Tutor sudah selesai merekam, video faststone bisa disisipkan lagu - lagu anak supaya Mahasiswa tidak bosan dalam mendengarkan video pembelajaran. Video pembelajaran yang sudah selesai dibuat akan diunggah di youtube sebagai sumber belajar (Setiadi dkk., 2019) dengan memberikan link video pembelajaran kepada mahasiswa melalui grup WA (Sianipar, 2013). Diharapkan dengan media pembelajaran berupa faststone dapat menambah pengetahuan para tutor di bidang teknologi serta memberikan pelayanan kepada Mahasiswa agar pembelajaran terus berjalan meskipun dalam kondisi pandemi covid-19. Kreatifitas tutor di dalam mendesain video tersebut dituntut penguasaan teknologi dan akses internet(Fuadi dkk., 2020; Mujianto, 2019; Lewandowski, 2015; ) untuk menarik minat mahasiswa dalam pembelajaran.

Berdasarkan latar belakang dan identifikasi masalah diatas,maka rumusan masalah dalam penelitian ini adalah: (1) Bagaimana peningkatan keaktifan Mahasiswa dalam pembelajaran menulis karya ilmiah menggunakan media faststone di masa pandemi covid-19 pada Mahasiswa Prodi PGSD FKIP Universitas Terbuka Surakarta Tahun Akademik 2020.1?; (2) Bagaimanakah peningkatan hasil belajar menulis karya ilmiah menggunakan media faststone di masa pandemi covid-19 pada Mahasiswa Prodi PGSD FKIP Universitas Terbuka Surakarta Tahun Akademik 2020.1?

Berdasarkan rumusan masalah di atas penelitian ini bertujuan untuk : (1) Memperoleh deskripsi tentang peningkatan keaktifan Mahasiswa dalam pembelajaran menulis karya ilmiah menggunakan media faststone di masa pandemic covid-19 padaMahasiswa Prodi PGSD FKIP Universitas Terbuka Surakarta Tahun Akademik 2020.1; (2) Memperoleh deskripsi tentang peningkatan hasil belajar Mahasiswa dalam pembelajaran menulis karya ilmiah menggunakan media faststone di masa pandemic covid-19 pada Mahasiswa Prodi PGSD FKIP Universitas Terbuka Surakarta Tahun Akademik 2020.1.

\section{Metode Penelitian}

Bentuk penelitian yang akan peneliti lakukan adalah penelitian tindakan kelas (class action research). Subjek dalam penelitian ini adalah Mahasiswa Prodi PGSD FKIP Universitas Terbuka Surakarta Tahun Akademik 2020.1. Kelas IA ini terdiri dari 28 mahasiswa, yaitu 7 laki-laki dan 21 perempuan. 
Penelitian ini dilaksanakan Prodi PGSD FKIP Universitas Terbuka Surakarta secara daring. Penelitian dilaksanakan pada semester 7Tahun Akademik 2020.1 yakni bulan Oktober-November 2020

Teknik pengumpulan data yang digunakan adalah observasi secara daring, dokumentasi dan wawancara secara daring. Observasi digunakan untuk mengumpulkan data yang terkait dengan pengamatan pada aktivitas proses pembelajaran Mahasiswa dan tutor. Dokumentasi digunakan untuk memperoleh informasi tentang dokumen kegiatan pembelajaran berupa foto atau informasi hasil tugas tutorial dalam bentuk nilai tutor. Wawancara daring digunakan untuk mengetahui informasi tentang respon Mahasiswa terhadap pembelajaran yang digunakan tutor berupa penggunaan media. Pendekatan dalam penelitian ini menggunakan pendekatan kualitatif deskriptif. Teknik analisis data dalam penelitian ini menggunakan teknik triangulasi data yang terdiri dari (1) pengumpulan data; (2) reduksi data; (3) penarikan simpulan.Dalam tindakan ini Peneliti menyusun dan membahas perencanaan yang akan dilakukan pada kegiatan pelaksanaan tindakan yang meliputi perencanaan, pelaksanaan tindakan dan observasi, serta refleksi.

\section{Hasil dan Pembahasan}

1. Pra Siklus

Pra Siklus dilaksanakan pada hari Rabu, 7 Oktober 2020. Hasil dari penelitian ini diperoleh datadata sebagai berikut :

Dalam perencanaan kegiatan yang dilakukan yaitu membuat skenario pembelajaran. Menyusun rencana pelaksanaan pembelajaran. Membuat alat peraga yang digunakan. Menyiapkan alat bantu mengumpulkan data. Menyusun alat evaluasi.

Pelaksanaan kegiatan ini yaitu sesuai dengan yang direncanakan, adapun kegiatannya meliputi : orientasi dan kegiatan pembelajaran. Pelaksanaan kegiatan pembelajaran ini sesuai dengan rencana kegiatan yang telah dibuat sebelumnya. Mengadakan evaluasi akhir pra siklus. Mengkoreksi hasil pekerjaan Mahasiswa .

Berdasarkan hasil observasi kepada Mahasiswa kelas I A dimana pada Pra Siklus diketahui bahwa perhatian Mahasiswa selama kegiatan pembelajaran masih belum bisa fokus terhadap materi pembelajaran yang diberikan, sehingga perlu direncanakan kembali pembelajaran yang serupa dan dipertinggi kegiatan memotivasi belajar Mahasiswa sehingga Mahasiswa lebih semangat dalam belajar serta tutor harus lebih variasi dalam strategi pembelajaran dan penggunaan alat peraga.

Dalam tahapan Refleksi, berdasarkan hasil tes akhir pada tahap Pra Siklus diperoleh hasil belajar Mahasiswa melalui deskripsi pada tabel. Pada pelaksanaan pra tindakan/pra siklus yang telah dilakukan, hasil keterampilan menulis karya ilmiah Mahasiswa masih rendah. Dalam menulis karya ilmiah maka nilai rata-rata kelas yaitu 74,14 dan dari 28 Mahasiswa ada 12 Mahasiswa yang sudah tuntas dalam menulis karya ilmiah dan 16 Mahasiswa belum tuntas dalam kegiatan menulis karya ilmiah. Karena KKM yang ditetapkan adalah 75.
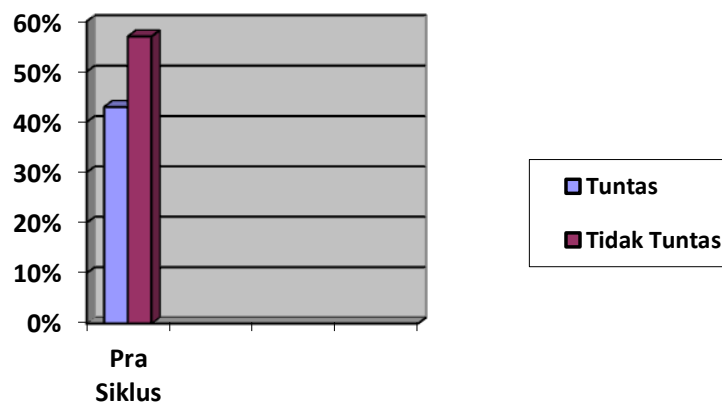

Gambar 1. Diagram rata-rata ketuntasan 
Dilihat dari diagram pada gambar 1, Mahasiswa yang tuntas hanyalah $43 \%$ dari total Mahasiswa sebanyak 28 Mahasiswa dan yang belum tuntas adalah 57\% dari total 28 Mahasiswa. Sedangkan kriteria ketuntasan kelas yang ditetapkan adalah jika $80 \%$ dari jumlah Mahasiswa sudah mencapai KKM. Dari data tersebut terlihat bahwa lebih banyak Mahasiswa yang belum tuntas daripada Mahasiswa yang sudah tuntas.

2. Siklus I

Deskripsi siklus I dilaksanakan pada hari Rabu, 14 Oktober 2020 selama 120 menit melalui media faststone. Pada pertemuan ini yang dilakukan adalah sebagai berikut :

a) Melakukan apersepsi, tutor menunjukkan alat dan bahan untuk menulis seperti buku, akses jurnal online. Hal ini untuk membuat Mahasiswa menjadi terfokus pada media pembelajaran dan termotivasi untuk belajar bersama.

b) Tutor membuka pelajaran dengan menunjukkan beberapa bagian-bagian karya ilmiah di dalam media videofaststone dan Mahasiswa memperhatikan yang dicontohkan tutor dengan baik. Untuk mengetahui Mahasiswa menulis karya ilmiah yang terdapat dalam media faststone, Mahasiswa mulai belajar menulis sesuai contoh.

c) Tutor membimbing Mahasiswa melalui media faststone bagaimana menulis karya ilmiah yang benar. Setelah itu Mahasiswa mengerjakan menuliskan urutan bagian karya ilmiah yang tepat .

Observasi siklus I dilakukan oleh peneliti I selama kegiatan pembelajaran berlangsung. Dalam observasi ini yang diamati adalah kegiatan-kegiatan Mahasiswa, kegiatan-kegiatan tutor selama pelaksanaan tindakan dan penggunaan media selama pembelajaran menulis karya ilmiah melalui aplikasi microsoft teems yang digunakan dalam tutoril web. Kegiatan-kegiatan tersebut tercantum dalam uraian sebagai berikut :

a) Kegiatan Mahasiswa

Pembelajaran menulis karya ilmiah dengan media faststone membuat Mahasiswa lebih antusias dan lebih fokus terhadap materi yang disampaikan tutor melalui media faststone. Disamping itu Mahasiswa juga aktif saat kegiatan pembelajaran berlangsung, hal ini di buktikan dengan keaktifan Mahasiswa saat menulis karya ilmiah dan pada saat tanya jawab. Pada siklus I ini masih ada beberapa Mahasiswa yang masih menulis belum sesuai format penulisan karya ilmiah, ada beberapa Mahasiswa yang bentuk formatnya kurang sesuai dan tidak sesuai template jurnal. Hal ini dibuktikan dengan masih adanya nilai yang di bawah KKM.

b) Kegiatan Tutor

Sebelum pembelajaran tutor sudah memberikan apersepsi dengan baik dan membawa minat Mahasiswa dalam rencana pembelajaran yang telah disusun, tutor sudah menjelaskan materi dengan baik dan jelas, tutor juga sudah memanfaatkan media dengan baik. Akan tetapi pada saat menjelaskan materi masih terlalu cepat dan masih belum menjelaskan secara tuntas sehingga Mahasiswa belum jelas. Kegiatan tutor masih kurang karena tutor hanya bergerak melalui media faststone sehingga belum mampu mengakomodir seluruh Mahasiswa . Tutor kesulitan menyimak Mahasiswa menulis secara individu karena jaringan internet yang stabil.

c) Media Faststone

Media faststone yang digunakan dalam pembelajaran menulis karya ilmiah aspek menulis sudah dapat meningkatkan motivasi dan keterampilan membaca modul Mahasiswa . Akan tetapi pembuatan media faststone masih dengan waktu yang kurang lama sehingga Mahasiswa yang di rumah merasa cepat belajarnya

Pada tahap Refleksi dan Revisi Tindakan siklus I peneliti melakukan analisis data yang telah terkumpul dari hasil observasi tutor, Mahasiswa, media dan analisis hasil evaluasi pembelajaran menulis Mahasiswa. Hasil dari analisis data tersebut dijadikan acuan untuk melakukan perbaikan pada tindakan selanjutnya.

Berdasarkan hasil refleksi, pembelajaran menulis karya ilmiah dengan menggunakan media 
faststone terdapat beberapa Mahasiswa yang masih mengalami kesulitan, beberapa kesulitan tersebut adalah : a) masih ada beberapa Mahasiswa yang mengalami kesulitan saat membedakan karya ilmiah hasil penelitian dengan non hasil penelitian yang mirip bentuknya, b) kesulitan menulis karya ilmiah,

Pembelajaran menggunakan media faststone dapat meningkatkan keterampilan menulis pada Mahasiswa di Prodi PGSD FKIP Universitas Terbuka Surakarta. Tetapi, untuk hasil yang lebih baik maka peneliti perlu adanya revisi diantaranya yaitu : Menulis karya ilmiah hasil penelitian dan non hasil penelitian.

Pembelajaran menulis dengan menggunakan media faststone pada siklus I dapat meningkatkan keterampilan menulis karya ilmiah pada Mahasiswa Prodi PGSD FKIP Universitas Terbuka Surakarta .

Peningkatan ini dapat dilihat dari diagram perbandingan ketuntasan. Dari gambar diagram dibawah dapat diketahui bahwa pembelajaran menggunakan media video faststone dapat meningkatkan hasil belajar Mahasiswa dalam menulis karya ilmiah, rata-rata siklus I 78,79 dan ketuntasan Mahasiswa 20 Mahasiswa pada siklus I. untuk lebih jelasnya perhatikan diagram berikut

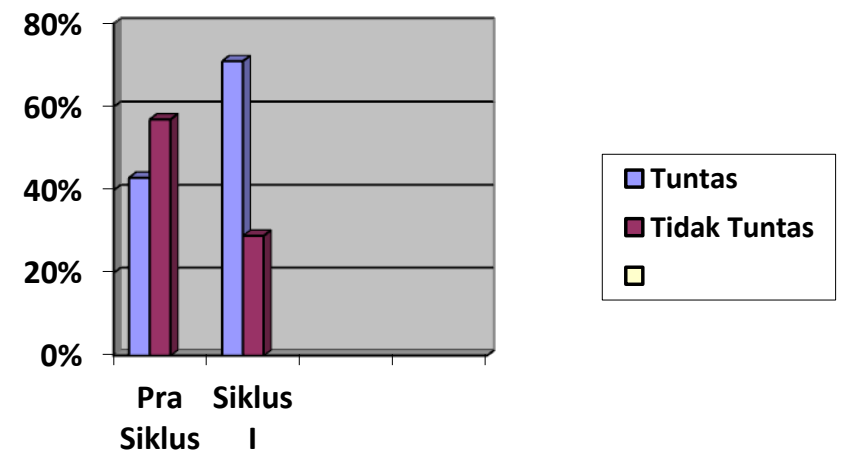

Gambar 2. Diagram perbandingan ketuntasan siklus I

Dari diagram pada gambar 2 dapat dilihat bahwa ketuntasan Mahasiswa mengalami peningkatan sebanyak 28\% atau sebanyak 20 Mahasiswa, yang semula 12 Mahasiswa menjadi 20 Mahasiswa dan yang semula $43 \%$ menjadi $71 \%$.

3. Siklus II

Deskripsi Siklus II dilaksanakan pada hari Rabu, 21 Oktober 2020 selama 120 menit. Pada pertemuan ini yang dilakukan adalah sebagai berikut :

a) Melakukan apersepsi.

Tutor menunjukkan alat dan bahan untuk menulis. Hal ini untuk membuat Mahasiswa menjadi terfokus pada media pembelajaran dan termotivasi untuk belajar bersama, tutor membuka pelajaran dengan menunjukkan beberapa huruf di media faststone dan Mahasiswa menulis huruf yang dicontohkan tutor dengan lafal dan intonasi yang tepat, tutor membimbing melalui instruksi.

b) setelah itu Mahasiswa menuliskan karya ilmiah melui contoh yang sudah diberikan tutor.

Hasil Observasi Siklus II adalah sebagai berikut:

a) Kegiatan Mahasiswa

Pembelajaran yang menggunakan media faststone pada siklus II menjadikan Mahasiswa lebih aktif dalam mengikuti pembelajaran menulis karya ilmiah. Hal ini terbukti dengan meningkatnya jumlah Mahasiswa yang aktif dalam menulis karya ilmiah dan diskusi yang terjadi dalam pembelajaran, kesalah-kesalahan semakin berkurang dan tulisan-tulisan Mahasiswa semakin terarah. Tetapi diantara peningkatan-peningkatan tersebut masih ada beberapa Mahasiswa yang masih belum mampu menulis karya ilmiah dengan maksimal, dan nilainya juga masih dibawah KKM yang ditetapkan. 
b) Kegiatan Tutor

Pada saat pembelajaran berlangsung tutor sudah mampu mengoperasikan media faststone dengan baik, saat menjelaskan materi juga cukup jelas karena bagian-bagian yang belum dipahami Mahasiswa di ulang dan dijelaskan kembali oleh tutor. Tutor telah memberikan kesempatan kepada Mahasiswa untuk menanyakan hal-hal yang belum dipahami oleh Mahasiswa, tutor juga membimbing Mahasiswa yang mengalami kesulitan menulis dalam kerja individu.

Dari hasil refleksi, Pembelajaran menggunakan media faststone masih terdapat beberapa Mahasiswa yang mengalami kesulitan. Kesulitan tersebut yaitu :

a. Tiga Mahasiswa masih belum menguasai menulis karya ilmiah dengan baik, itu terlihat karena masih belum benar ketika menulis.

b. Dua Mahasiswa masih belum bisa membedakan karya ilmiah hasil penelitian dan non hasl penelitian.

Pembelajaran menulis karya ilmiah dengan menggunakan media videofaststone pada siklus I dapat meningkatkan keterampilan menulis karya ilmiah pada mahasiswa Prodi PGSD FKIP Univerrsitas Terbuka Surakarta. Peningkatan ini dapat dilihat dari gambar diagram. Dari gambar diagram di bawah dapat diketahui bahwa keterampilan menulis karya ilmiahmahasiswa mengalami peningkatan dilihat dari nilai rata-rata awal pada siklus I, serta diihat dari persentase pada Siklus II.

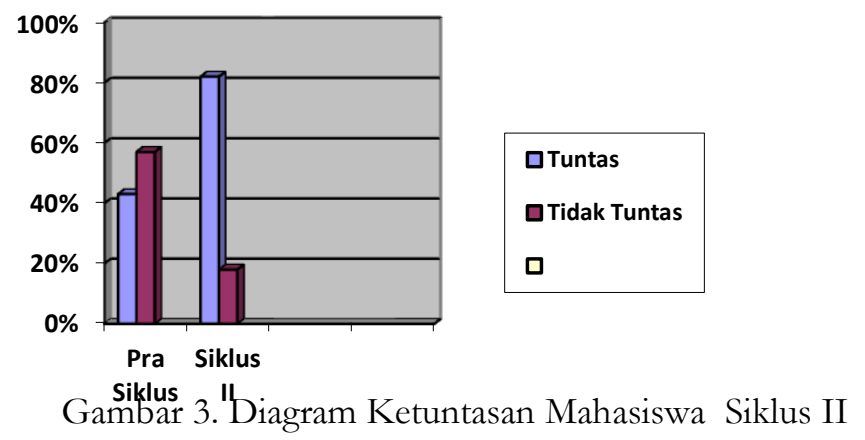

Pada Siklus II peningkatan yang terjadi sebanyak 39\% (5 Mahasiswa) dari kondisi awal siklus I $28 \%$ (5 Mahasiswa ) menjadi 82\% (23 Mahasiswa ). Dari kegiatan pembelajaran pada Siklus I sampai siklus II dapat diketahui bahwa pelaksanaan pembelajaran dengan menggunakan media video faststone yang dilaksanakan pada siklus I dan siklus II mengalami peningkatan. Pada siklus I diperoleh hasil 78,79 dan pada siklus II mengalami peningkatan menjadi 80,11. Dari hasil tindakan pembelajaran tersebut diketahui bahwa pada siklus II sudah mencapai KKM karena KKM Teknik Penulisan Karya Ilmiah yang ditentukan adalah 75 .

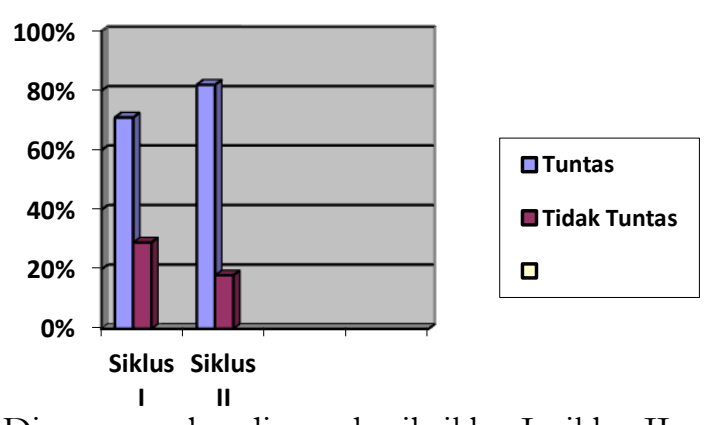

Gambar 4. Diagram perbandingan hasil siklus I, siklus II

Dari diagram diatas ketuntasan Mahasiswa pada setiap tindakan mengalami peningkatan, hal itu bisa terlihat dari persentase pada setiap siklus. Pada siklus I 71\% dan pada siklus II meningkat menjadi $82 \%$. Hasil ini sudah mencapai kriteria yang ditetapkan oleh peneliti. 
Berdasarkan data pada Prasiklus, Siklus I dan Siklus II dapat disimpulkan bahwa pembelajaran menulis karya ilmiah menggunakan media video Faststone dapat meningkatkan hasil belajar menulis karya ilmiahMahasiswa pada kelas I A Prodi PGSD FKIP UT Surakarta. Dengan menggunakan media Faststone ini selain meningkatkan hasil belajar kemampuan menulis karya ilmiah juga meningkatkan keaktifan Mahasiswa selama pembelajaran sehingga akhirnya dapat meningkatkan hasil belajar Mahasiswa. Hal ini menunjukkan Media sebagai sebuah saluran untuk komunikasi yang digunakan menyalurkan informasi antara pengirim dan penerima (Darmuki dkk., 2017) dengan arti kata media adalah segala sesuatu yang dapat digunakan untuk menyalurkan pesan dan dapat merangsang pikiran, perasaan, perhatian, dan kemampuan Mahasiswa sehingga dapat mendorong terjadi proses belajar pada diri Mahasiswa (Darmuki dkk, 2019; Darmuki \& Hidayati, 2019; ).

\section{Kesimpulan}

Berdasarkan pelaksanaan penelitian tindakan kelas yang telah dilakukan dapat disimpulkan bahwa menggunakan media video faststone pada pembelajaran menulis karya ilmiah dapat meningkatkan keaktifan Mahasiswa Prodi PGSD FKIP Universitas Terbuka Surakarta selama pembelajaran daring berlangsung, 2) Menggunakan media video faststone pada pembelajaran menulis karya ilmiah dapat meningkatkan hasil belajar pada Mahasiswa Prodi PGSD FKIP Univerrsitas Terbuka Surakarta

Selama kegiatan penelitian dan pembelajaran daring berlangsung, semua berjalan dengan baik. Keterlibatan Mahasiswa selama pembelajaran daring juga sudah berlangsung dengan baik. Peningkatan hasil belajar Mahasiswa juga terlihat dari hasil penelitian dan hasil Mahasiswa yang menunjukkan telah mengalami ketuntasan KKM yang ditetapkan.

\section{Daftar Pustaka}

Anhusadar, L. O. (2020). Persepsi Mahasiswa PIAUD terhadap Kuliah Online di Masa Pandemi. KINDERGARTEN: Journal of Islamic Early Childhood Education, 3(1), 44-58.

Baskoro, A. (2009). Panduan Praktis Searching di Internet. Jakarta : PT Trans Media.

Burke, S.C., Snyder, S., Rager, R.C. (2009). An Assessment of Faculty Usage of Youtube as a Teaching Resource. The Internet Journal of Allied Health Sciences and Practice. Vol. 7(1), 8

Darmuki, Agus. (2020).Upaya Meningkatkan Kemampuan Berbicara Mahasiswa Menggunakan Media Aplikasi Google Meet Berbasis Unggah Tugas Video Di Youtube Pada Masa Pandemi Covid-19. Jurnal Educatio FKIP UNMA, Vol 6(2),655-661.

Darmuki, A. \& Ahmad Hariyadi. (2019). Eksperimentasi Model Pembelajaran Jucama Ditinjau Dari Gaya Belajar Terhadap Prestasi Belajar MahaMahasiswa Mata Kuliah Berbicara Di Prodi PBSI IKIP PGRI Bojonegoro. Kredo. 3(1), 62-72.

Darmuki, A. \& Hidayati N.A. (2019). An Investigation of The Cooperative Learning Using Audio Visual Media in Speaking Skill Subject. ICSTI. 121-126.

Darmuki, A. \& Hidayati, N.A. (2019). Peningkatan Kemampuan Berbicara Menggunakan Metode Kooperatif Tipe NHT pada MahaMahasiswa Tingkat I-A Prodi PBSI IKIP PGRI Bojonegoro Tahun Akademik 2018/2019. Jurnal Pendidikan Edutama. Vol. 6(2), hlm 9-18.

Darmuki, A., Ahmad Hariyadi. (2019). Peningkatan Keterampilan Berbicara Menggunakan Metode Kooperatif Tipe Jigsaw pada MahaMahasiswa PBSI Tingkat IB IKIP PGRI Bojonegoro Tahun Akademik 2018/2019. Kredo. 2(2), 256-267.

Darmuki, A., Andayani, Joko N., Kundharu S. (2017). Cooperative, Synectics, and CTL Learning Models Toward Speaking Ability Viewd from Students Motivation. Proceeding International Conference on Intellectuals'Global Responsibility (ASSEHR). Vol. 125, 75-79. 
Darmuki, A., Andayani, Joko N., Kundharu S. (2017). Evaluating Information-Processing-Based Learning Cooperative Model on Speaking Skill Course. Journal of Language Teaching and Reasearch. 8(1) pp. 44-51.

Darmuki, A., Andayani, Joko N., Kundharu S. (2018). The Development and Evaluation of Speaking Learning Model by Cooperative Approach. International Journal of Instruction. 11(2), 115-128.

Darmuki, A., Ahmad Hariyadi, Nur Alfin Hidayati. (2019). Developing Beach Ball Group Investigations Cooperative. International ConferencesSeword Fresh, 1-7.

DeWitt, D., Alias, N., Siraj, S., Yaakub, M. Y., Ayob, J., \& Ishak, R. (2013). The potential of Youtube for teaching and learning in the performing arts. Procedia-Social and Behavioral Sciences, 103, 1118 $-1126$.

Fuadi, T. M., Musriandi. R., \&Suryani, L., (2020). Covid-19 : Penerapan Pembelajaran Daring Di Perguruan Tinggi. Jurnal Dedikasi Pendidikan, 4(2), 193-200.

Lewandowski, M. (2015). Creating Virtual Classrooms (Using Google Hangouts) For Improving Language Competency. Language Issues: The ESOL Journal 26(1): 37-42.

Mujianto, H. (2019). Pemanfaatan Youtube sebagai Media Ajar dalam Meningkatkan Minat dan Motivasi Belajar. Jurnal Komunikasi Hasil Pemikiran dan Penelitian. Vol. 5(1), 135-159.

Sarmadan. (2017). Pengembangan Bahan Ajar Menulis Karya Ilmiah dalam Pengajaran Bahasa Indonesia di STIKOM Kota Jambi. Jurnal Ilmiah Universitas Batanghari Jambi, Vol. 17(1), 159171.

Setiadi, E. F., Azmi, A., \& Indrawadi, J. (2019). Youtube Sebagai Sumber Belajar Generasi Milenial. Journal of Civic Education, 2(4), 313-323.

Sianipar, A. P. (2013). Pemanfaatan youtube di kalangan Mahasiswa . Jurnal Ilmu Komunikasi FLOW, 2(3), 1-10.

Rohandi, Y. (2020). Teaching EFL Students Using Selected Media: Offline Video Taken From YouTube. The journal of Ultimate Research and Trends in Education. Vol 2(1), 29-33.

Zahroh, H. (2017). Pengembangan Model Bahan Ajar Video Kreatif Terpimpin Edukatif (KTE) untuk Pembelajaran Menulis Karya Ilmiah Sederhana Peserta Didik Kelas IX SMP Mamba'ur Bululawang. Jurnal Inovasi Pembelajaran. Vol. 3 (1), 469-482. 